\title{
Impact of foreign direct investment (FDI) on GDP: A Case study from Pakistan
}

\author{
Nadeem lqbal ${ }^{1, *}$, Naveed Ahmad ${ }^{2}$, Zeeshan Haider ${ }^{1}$, Sonia Anwar ${ }^{1}$ \\ ${ }^{1}$ Faculty of Management Sciences, Bahauddin Zakariya University, Bosan Road, \\ Multan 60000, Pakistan \\ ${ }^{2}$ Faculty of Management Sciences, Indus International Institute, D. G. Khan, Pakistan \\ *Email address: drnadeemiqbal1@gmail.com
}

\begin{abstract}
This research study is related to FDI and GDP and the main aim of this research study is to validate the relationship between them. Foreign direct investment (FDI) is considered as a growth accelerating component that has received a great attention in developed countries even in developing and less developed countries during recent years. Now FDI has greater importance in closed economy. FDI benefits any economy in terms of technology, skilled labor and skills transfer to the host countries. For data collection, 30 year data from 1983 to 2012 was collected and the cobb-Douglas Production function is used to test the relationship. Our research variables are Gross Capital Formation (K), Labor (L), Health Expenditure (H), FDI and openness to trade in export oriented economy (OP*FDI). We have followed the Bhagwati's hypothesis that was: FDI has greater impact on GDP in the export oriented economy. For data analysis, we have examined the descriptive statistics, correlation and regression model. For this we incorporate the production function in regression model. In brief, our results show that there is a positive relationship between FDI and GDP in Pakistan. But, Pakistan has not sufficient flow of FDI during past decades. And main point to consider which is evident through statistics and results is that there is greater impact of FDI in the open trade policy regimes. It is also concluded that FDI impact may be situation and culture related. So, the extent of FDI economic benefits cannot be predicted.
\end{abstract}

Keyword: FDI; GDP; Labor; Capital; Export Promotion policy; Cobb-Douglas production function

\section{INTRODUCTION}

Foreign direct investment (FDI) as a growth accelerating component has received a great attention in developed countries even in developing and less developed countries during recent years. It has been a matter of greater concern for the economists how FDI affects economic growth of the host country' economy. In closed economy there is no access to the foreign instruments and savings, this type of economy solely based on the domestic savings and investment sources. But in open economy, the investment comes from both sources either from domestic savings or foreign capital inflows like FDI. FDI enables the host country to achieve the investment level beyond its capacity to improve GDP and economic growth. In 1997 FDI has accounted for $45 \%$ of net foreign resource flows to developing countries as compared with $16 \%$ in 1986 (Perkins, 2001). Furthermore, the World Bank (2002) reported that in 1997 developing nations has received $36 \%$ of the total FDI flows. Many of the studies demonstrate 
that there is a positive relationship between FDI and GDP of the host countries while this study focuses on the impact of FDI on GDP and its role in the developing country's economy. Balasubramanyan et al. (1996) found that FDI accelerate the economic growth of the host country and its impact is relatively stronger for the countries which have outward oriented trade policies.

De Mello (1999) suggested that FDI has the greater importance to improve the economic growth that depends on its exogenous factors like skilled labor and its impact on country and condition specific. Todaro and Smith (2003) and Hayami (2001) argue that the flow of FDI fills the gap between desired and domestic investment level and it also increase the tax revenues, effective management and technology as well as skilled labor in the host countries. According to jenkin and Thomas (2002) FDI is expected to contribute to the economic growth of the host countries. According to Accoley (2003); Fedderke and Romm (2006) Nonnemberg and Caroso de Mendonca (2004) elaborate that economic growth is one of the determinant responsible for higher FDI inflow.

While Alfaro (2003) has found ambiguous relationship between FDI and GDP and also argue that its impact on host country varies according to the types of policies that host country adopts for its trade and FDI regulations. Adegbite and Ayadi (2010) assert that FDI helps to fill the domestic revenue-generation gap in developing economy because most developing economies have not sufficient capital to generate revenue to meet their expenditure needs. Firstly, the main ground that induces the author to study this stated relationship is that although there have been ample studies in this respect but these studies found ambiguous relationship in the host country. For this reason author is doing study in this respect to find the relationship between FDI and GDP.

As FDI is major component of capital flow for developing countries, its contribution towards economic growth is widely argued, but most researchers concur that the benefits outweigh costs on the economy (Musila and Segue, 2006; Mc Aleese, 2004). Secondly, author wants to describe the role of FDI in the developing countries economy. FDI alleviate economic growth in the developing countries, this has greater attention and significant for the economists and policy makers, due to following reasons: First, FDI provides an ease to developing countries to access and learn new technology, make management and labor skilled and effective.

Second, through FDI, host countries increase the surplus of capital account and help to improve or rectify the trade balances. Thirdly, as developing host countries have lower rates of capital accumulation and thus FDI provides an opportunity to support domestic investment to increase economic growth. "FDI represent a package of potential growth heightening attributes - improved or raised GDP" (Mc Aleese, 2004; Boransz tain De Gregorio and Lee 1998; \& Collier and Dollar, 2001).

\section{LITERATURE REVIEW}

Farkas (2012) tested the effect of FDI on GDP by doing the regression analysis and concluded the results that FDI has positive relationship with GDP and its impact depend upon the absorptive capacity of the host country, level of human capital and development of the financial markets. Hameed and Bashir (2012) conduct a study on the MENA countries to see the impact of FDI on GDP via using econometric model. They come to this conclusion that FDI leads to Economic Growth but varies according to region and over time. They also investigated that FDI is affected by domestic investment and openness to international trade. 
Onakoya (2012) seeks the impact of FDI on GDP in different sectors of Nigeria country through using three-stage least square (3SLQ) technique and Macro Econometric model of simultaneous equation. He found that FDI affect the GDP but significantly cast an impact on the output of that economy. Zeeshan and Antique (2012) investigated the relationship of FDI and GDP in Pakistan. Cobb - Douglas Production function was used along with regression equation to draw conclusion from data period of 1971-2001.

He concluded that the effects of Imports substitution and exports oriented economies is different and support the Bhagwati's hypothesis which means FDI's spillover effect in much greater in the latter economy than the former economy. Tue anh and et al. (2010) do the study in the Vietnam to see the spillover effects of FDI in its economy. Endogenous growth model is used and get the results that there is little evidence of spillover effects of FDI at micro level. Makki and Somwaru (2009) seek the impact of FDI on trade and economic growth in 66 developing countries by using cross sectional data.

They concluded that FDI interacts positively with trade and FDI promotes domestic investment. It has been also concluded that sound policies and stability are the preconditions for FDI to increase GDP rate. All results are drawn by using econometric model for production function. Karimi \& et al. (2009) conducted the study in Malaysia and used time series data from 1970 to 2005. Methodology was based on Toda Yarn Moto test for causality effect on relationship and Bounds testing (ARDL).

They draw the conclusion that FDI has indirect effect on GDP. Noormamode (2008) seek the impact of FDI on economic growth and also studied that host country social and economic conditions matter on FDI spillover effects. A panel VAR model was used and found that there is no clear cut evidence on growth effects of FDI. Turk can and et al. (2008) studied the endogenous relationship between FDI and GDP through panel data of 23 OECD countries for the time series from 1975 to 2004. For this purpose they used two simultaneous equations coupled with generalized methods of moments and draw the conclusion that both factors affect the economy and FDI is the major contributor to accelerate the GDP rate and GDP determinates the level of FDI in most cases.

Johnson (2005) studied the impact of two FDI's spillovers technology and human capital in 90 countries that covered time period of 1980-2002 and regression equation was used to analyze the panel data. He found that FDI inflow enhance GDP in developing countries not in developed counties.

Athukorala (2003) studied the impact of FDI on GDP in the context of Sri Lanka and found that FDI contributes to accelerate the GDP rate but it is not a sole factor that affects GDP. In order to gain these results, he used Econometric framework because regression was proved not so much supportive in that context. Akinlo (2003) and Adelegan (2000) found that foreign funds inflow is not statistically significant to increase the level and rate of economic growth in Nigeria and mostly in developing host countries. Furthermore FDI is negatively related with domestic investment. This result is drawn using seemingly un-related regression (SURE).

De Mello (1999) used panel data and time series data of 32 developed and developing countries from 1970-1990 to investigate the impact of FDI on GDP. In order to draw results he used Stationarity tests but results showed weak relationship between FDI \& GDP. 


\section{CONCEPTUAL MODEL}

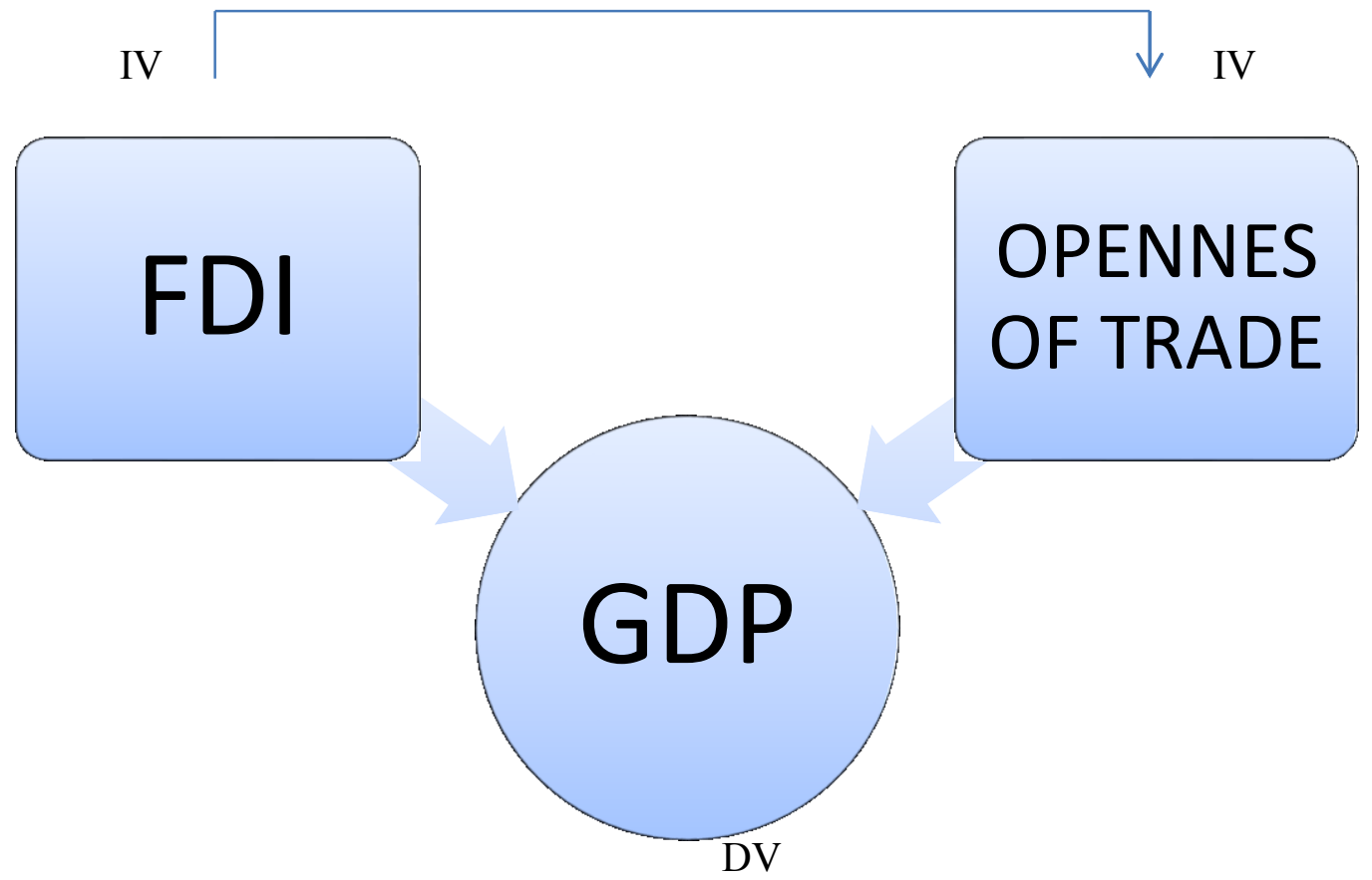

\section{HYPOTHESIS}

H1: There is positive relation between FDI and GDP in Pakistan.

$\mathrm{H} 2$ : There is greater positive impact of FDI via Openness of trade on GDP in Pakistan (as hypothesized by Bhagwati's).

\section{MODEL SPECIFICATION}

This model consists of three variables; two independent factors and one dependent factor i.e. Foreign Direct Investment (FDI), Gross Domestic Product (GDP) and openness to trade (OP). The FDI is the flow of capital from the multinational corporations and foreign countries that brings capital formation advantage, technological advancement and skilled human capital in less developed countries or host countries like Pakistan. FDI also serves as potent weapon for developing countries in achieving the socioeconomic goals like reduction in poverty and highly skilled labor. On the other hand, Openness to trade (OP) summarizes international transaction (Exports and Imports) record for the specific period of time in specific currency (in the concerned country currency).

Its balance may be zero, in surplus or may be deficit. If Exports exceeds imports then there will be surplus, or otherwise it will be deficit and if they equate with each other there will be zero balance. With all this OP contributes a lot to the any country economic growth i.e. GDP. And, the Gross Domestic Product (GDP) is the measure of economic growth of any country. It drives from the technological advancement, growth in the physical capital stock, growth in employment, growth in the skilled human capital and progress in institutions Education \& Health. For this research study the author has used the Cobb - Douglas production function that is: 


$$
\mathrm{Y}=\mathrm{AK}^{\mathrm{a}} \mathrm{L}^{\mathrm{b}}
$$

For study convenience and to incorporate all study related variables, the following modifications in model of study is made:

$$
\mathrm{Y}=\mathrm{f}(\mathrm{L}, \mathrm{K}, \mathrm{H}, \mathrm{FDI}, \mathrm{OP})
$$

Here, Y represents GDP, $\mathrm{L}$ is labor force, $\mathrm{K}$ is the Capital, FDI is Foreign Direct Investment and OP is Openness to trades. This equation states that all these factors positively contribute toward economic growth (GDP) of a country. In this regard, author has taken the net export and an import balances as a proxy to incorporate the OP. Then research related estimated regression equation will be:

$$
\mathrm{Y}=\mathrm{B}_{0}+\mathrm{B}_{1} \mathrm{~L}+\mathrm{B}_{2} \mathrm{~K}+\mathrm{B}_{3} \mathrm{H}+\mathrm{B}_{4} \mathrm{FDI}+\mathrm{B}_{5}(\mathrm{OP})
$$

While, $\mathrm{B}_{0}>0, \mathrm{~B}_{1}>1, \mathrm{~B}_{2}>0, \mathrm{~B}_{3}>0, \mathrm{~B}_{4}>0, \mathrm{~B}_{5}>0$

The coefficients $\mathrm{B}_{1}, \mathrm{~B}_{2}, \mathrm{~B}_{3}$ show that how much GDP change due to change in the Labor, Capital, Human capital, OP and FDI in the context of Pakistan.

\section{1. Data source and Data Period:}

The data collected from SBP (state bank of Pakistan), FBS, World Development Series and the Economic Surveys of Pakistan, for the period elapsed between 1982 to 2012. This data is collected and analyzed with an intention to see the trend of FDI, impact \& relationship of OP and FDI on the GDP in Pakistan.

\section{DATA ANALYSIS}

\section{1. Empirical results}

Firstly, The Descriptive Statistics of all variables are computed. In Descriptive statistics author computed Range, Minimum, Maximum, Mean and Standard Deviations values. These Descriptive statistics are shown here:

Table 1. Descriptive Statistics.

\begin{tabular}{cccccc}
\hline & Range & Minimum & Maximum & Mean & Std. Deviation \\
\hline GDP & .02 & .05 & .06 & .0546 & .00616 \\
FDI & 938.45 & 816.72 & 1755.17 & 1239.3933 & 379.78307 \\
Labor & 4.16 & 37.77 & 41.94 & 39.8560 & 1.62129 \\
Capital & 560.09 & 750.37 & 1310.45 & 965.0480 & 220.45717 \\
Health & 4620.69 & 5541.60 & 10162.29 & 7789.9943 & 1849.11763 \\
OP & 140948.83 & 186175.83 & 327124.67 & 252861.0333 & 59451.49972 \\
\hline
\end{tabular}


Secondly, author found correlation of all variables with each other. The correlation table shows that all variables have the positive relationship with each other especially, relationship of all independent variable with the independent variable i.e. GDP.

Table 2. Correlations (Pearson Correlation).

\begin{tabular}{ccccccc}
\hline & GDP & FDI & Labor & Capital & Health & OP \\
\hline GDP & 1 & .738 & $.972^{* *}$ & $.876^{*}$ & $.885^{*}$ & $.895^{*}$ \\
FDI & .738 & 1 & $.860^{*}$ & $.932^{* *}$ & $.913^{*}$ & $.905^{*}$ \\
Labor & $.972^{* *}$ & $.860^{*}$ & 1 & $.929^{* *}$ & $.925^{* *}$ & $.925^{* *}$ \\
Capital & $.876^{*}$ & $.932^{* *}$ & $.929^{* *}$ & 1 & $.992^{* *}$ & $.991^{* *}$ \\
Health & $.885^{*}$ & $.913^{*}$ & $.925^{* *}$ & $.992^{* *}$ & 1 & $.997^{* *}$ \\
OP & $.895^{*}$ & $.905^{*}$ & $.925^{* *}$ & $.991^{* *}$ & $.997^{* *}$ & 1
\end{tabular}

**. Correlation is significant at the 0.01 level (2-tailed).

*. Correlation is significant at the 0.05 level (2-tailed).

Thirdly, author used the regression equation to draw the results about all variables.

Table 3. Regression Coefficients ${ }^{\mathrm{a}}$

\begin{tabular}{|c|c|c|c|c|c|}
\hline \multirow[t]{2}{*}{ Model } & \multicolumn{2}{|c|}{$\begin{array}{c}\text { Unstandardized } \\
\text { Coefficients }\end{array}$} & \multirow{2}{*}{$\begin{array}{c}\text { Standardized } \\
\text { Coefficients } \\
\text { Beta }\end{array}$} & \multirow[t]{2}{*}{$\mathrm{T}$} & \multirow[t]{2}{*}{ Sig. } \\
\hline & B & Std. Error & & & \\
\hline (Constant) & .130 & .032 & & 3.997 & .001 \\
\hline FDI & $6.141 \mathrm{E}-007$ & .000 & .052 & .134 & .894 \\
\hline $\mathrm{L}$ & -.002 & .001 & -1.205 & -2.405 & .024 \\
\hline $\mathrm{K}$ & $1.641 \mathrm{E}-005$ & .000 & 1.010 & .738 & .467 \\
\hline $\mathrm{H}$ & $-4.746 \mathrm{E}-006$ & .000 & -2.328 & -2.143 & .042 \\
\hline OP & $1.547 \mathrm{E}-007$ & .000 & 2.687 & 1.479 & .152 \\
\hline
\end{tabular}

a. Dependent Variable: GDP

This table shows the regression analysis results that reveal the fact that FDI has the positive linkage with GDP as hypothesized by H1. But author also studied the main hypothesis of Bhagwati's which was: there is the greater impact of FDI on GDP in the Exports oriented economy than any imports substitution economy (as hypothesized in H2). As shown from the "T" statistics of the table, each variable of this model has sufficient significance level.

The Table 3 shows the change in GDP due to the change in the labor force, capital formation and health expenditures, FDI \& Policy regime (Openness to trade). FDI \& Policy regime relation with GDP are positive that explain their positive impact on the GDP. 
In brief, all hypothesis of this study are proved and has the predetermined relation and impact on each other. Lastly the findings of study are consistent with existing literature and the main hypothesis of Bhagwati's.

\section{CONCLUSION}

FDI plays a vital role in economic growth of any country. The past decades found its significant and positive impact of FDI on GDP in the host country. Pakistan's Literature is evident that the inflow of FDI in Pakistan is not so much significant, but has relatively increasing since Pakistan has adopted market oriented policies. This study has the motive to find the relationship between FDI and GDP and also to see the impact of trade policies on FDI role. Moreover, FDI stimulates human resource development through training, education, technology transfer, more employment and other spillover effects on the host country economy. In short, these finding describes that Pakistan Economic Growth capacity depends upon its ability to attract FDI and degree of FDI impact on GDP depends upon its trade policy regime that is Export Promotion policy.

\section{References}

[1] Adeniyi O., Omisakin O., Foreign Direct Investment, Economic Growth and Financial Sector Development in Small Open Developing Economies. Economic Analysis \& Policy 42(1) (2012).

[2] Agrawal G., Khan M. A., European Journal of Scientific Research 57(2) (2011) 257-264.

[3] Aizhan K., Macarena M. D. (2011). Impact of Foreign Direct Investment on Economic Growth in Kazakhstan International Conference on Sociality and Economics Development 10.

[4] Alfaro L. (2003). Foreign Direct Investment and Growth: Does the Sector Matter? Journal of Economics and Social Sciences.

[5] Athukorala P. P. A. W. (2003). The Impact of Foreign Direct Investment for Economic Growth: A Case Study in Sri Lanka. International Conference on Sri Lanka Studies.

[6] Atique Z., Ahmad M. H., Azhar U., The Pakistan Development Review 43(3) (2004) 707-718.

[7] Ayanwale A. B. (2007). FDI and Economic Growth: Evidence from Nigeria. AERC Research Pape, 33.

[8] Barro R., Journal of Political Economy 98(5) (1990) S103-S125.

[9] Borensztein E., J. De Gregorio, J. W. Lee, How Does Foreign Direct Investment Affects Economic Growth?, Working Paper No. 5057, Cambridge, MA:

[10] Borensztein E., Gregorio J. D., Lee, J.-W., Journal of International Economics 45 (1998) 115-135.

[11] Economic Survey of Pakistan, (2005-2012). Finance Division, Government of Pakistan. Federal bureau of statistics, finance Division, 2012. 
[12] Hussein M. A., Countries International Review of Business Research Papers 5(3) (2009) 362-376.

[13] Karimi, Sharif, M., Yusop, \& Zulkornain. (2009). FDI and Economic Growth in Malaysia. Munich Personal RePEc Archive.

[14] Khaliq A., Noy A., Foreign Direct Investment and Economic Growth: Empirical Evidence from Sectoral Data in Indonesia. Journal of Economics and Sustainable Development 7 (2007).

[15] Moss M., The Measurement of Economic and Social Performance. National Bureau of Economic Research (1997) 193-232.

[16] Onakoya A. B., Foreign Direct Investments and Economic Growth in Nigeria: A Disaggregated Sector Analysis Journal of Economics and Sustainable Development 3(10) (2012).

[17] Ray S. (2012). Impact of Foreign Direct Investment on Economic Growth in India: A Co integration Analysis Advances in Information Technology and Management (AITM), 2(1). www.sbp.pk.com

[18] Zhang K. H., FDI and economic growth in china. Journal of Economics and Sustainable Development 3 (2005).

\section{APPENDIX:}

Table 4. Regression Model Statistics.

\begin{tabular}{|c|c|c|c|c|c|c|}
\hline Model & $\mathrm{R}$ & R Square & $\begin{array}{l}\text { Adjusted R } \\
\text { Square }\end{array}$ & $\begin{array}{l}\text { Std. Error of the } \\
\text { Estimate }\end{array}$ & F Change & Sig. F Change \\
\hline 1 & $.592^{\mathrm{a}}$ & .351 & .215 & .0168810 & 2.592 & .052 \\
\hline
\end{tabular}

Table 5. ANOVA ${ }^{\mathrm{a}}$

\begin{tabular}{ccccccc}
\hline Model & Sum of Squares & Df & Mean Square & F & Sig. \\
\hline \multirow{4}{*}{1} & Regression & .004 & 5 & .001 & 2.592 & $.052^{\mathrm{b}}$ \\
& Residual & .007 & 24 & .000 & & \\
& Total & .011 & 29 & & & \\
\hline
\end{tabular}

a. Dependent Variable: GDP

b. Predictors: (Constant), OP, FDI, L, H, K 